\title{
Richard Rorty - heretyk i wieszcz
}

„Richard Rorty wyzwolił się przed trzydziestoma pięcioma laty z gorsetu dziedziny, której konwencje stały się dla niego zbyt ciasne - nie po to jednak, żeby uwolnić się z dyscypliny analitycznego myślenia, lecz żeby móc odtąd filozofować na niewydeptanych ścieżkach"

J ÜR G E N H A B E R M A S ${ }^{1}$

Doniżej zaprezentowany tekst jest fragmentem wywiadu-rzeki przeprowadzonego przez Dereka Nystroma i Kenta Pucketta z Richardem Rortym we wrześniu 1998 roku² $^{2}$ Publikowany w tym miejscu wycinek z całej konwersacji powinien zainteresować czytelnika ze względu na to, że Rorty opowiada w nim o kulisach swojej pracy na amerykańskich uniwersytetach, w mniejszym zaś stopniu o swojej filozofii. Nie jest problemem dla polskiego czytelnika zapoznanie się z koncepcjami filozoficznymi amerykańskiego myśliciela $\mathrm{z}$ racji tego, że jego klasyczne rozprawy zostały przetłumaczone na język polski i są one powszechnie dostępne. Poglądy Rorty'ego przybliżył również polskiemu światu akademickiemu Andrzej Szahaj w swojej rozprawie Ironia $i$ milość. Neopragmatyzm Richarda Rorty'ego w kontekście sporu

J. Habermas, Orchidee i spawiedliwość, przeł. A. Żychliński, dostępne: http://www.lewica.pl/ ?id=14332 [10.03.2007]. Tekst pochodzi z dziennika „Süddeutsche Zeitung” z 11 czerwca 2007 roku, jego polskie tłumaczenie zamieszczone zostało w miesięczniku „Odra”.

W tym miejscu pragnę podziękować panu dr. hab. Adamowi Grzelińskiemu, który przejrzał tłumaczenie, rozwiał moje wątpliwości co do niektórych jego fragmentów i zasugerował cenne poprawki. 
o postmodernizm, która po dziś dzień pozostaje najbardziej cenioną i poczytną pracą $\mathrm{w}$ kraju poświęconą temu myślicielowi. W publikowanym wywiadzie możemy prześledzić, jak przebiegała kariera akademicka autora Filozofii a zwierciadła natury, jak dokonywało się jego odejście od filozofii analitycznej i zbliżenie do literaturoznawstwa, co było asumptem do napisania przezeń kolejnych jego dzieł. Warto, chociażby skrótowo, dowiedzieć się, co o tym wszystkim myślał i jak swoją karierę oceniał sam Rorty, chociażby z tego względu, że 8 czerwca upłynie rok od śmierci tego wielkiego filozofa.

Richard Rorty zdobył gruntowne wykształcenie filozoficzne na amerykańskich uczelniach, choć wielokrotnie ubolewał nad swoimi brakami i niedostatkami. Magisterium z filozofii przygotowywał na Uniwersytecie w Chicago (1952), zaś doktorat obronił na prestiżowym amerykańskim Yale (1956). Początkowo interesował się platonizmem, jednakże bardzo szybko porzucił ten nurt i przeszedł na stanowisko filozofa analitycznego. Filozofia tak uprawiana przez pewien okres była dla niego filozofią przyszłości, jednakże już w wieku 25 lat zainteresował się pragmatyzmem w duchu Johna Dewey'a, który - w jego mniemaniu - „otworzył nowe drogi kulturalnego rozwoju"3. Duży wpływ na jego dojrzałą twórczość, poza wspomnianym Dewey'em, mieli również Willard Van Orman Quine, Wilfrid Sellars oraz Ludwig Wittgenstein. Pod koniec lat osiemdziesiątych i w latach dziewięćdziesiątych dostrzegalny jest również pewien wpływ filozoficznych koncepcji Martina Heideggera, który - według Rorty'ego - „pomaga zachować to wszystko, co było w tradycji najgorsze, a co miał nadzieję przezwyciężyć" Michela Foucaulta „pogardzającego własną skończonością, poszukującego jakiejś potężnej, nieludzkiej siły, by dla niej wyrzec się swej tożsamości” ${ }^{5}$ oraz Jacquesa Derridy, którego zwie „najnowszym i największym kwiatem

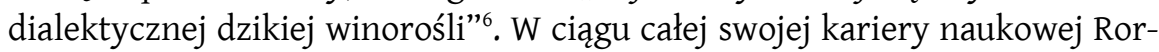
ty związany był z kilkoma uczelniami amerykańskimi. Po obronie doktoratu pracę rozpoczął na Wellesley College, w 1983 przeniósł się na University of Virginia, gdzie zatrudniony był jako profesor nauk humanistycznych. W roku 1998 przeszedł na Stanford University jako profesor literaturoznawstwa porównawczego ${ }^{7}$.

R. Rorty, Konsekwencje pragmatyzmu, przeł. Cz. Karkowski, Warszawa 1998, s. 130.

Tamże, s. 102.

Tamże, s. 204-205.

Tamże, s. 148.

R. Rorty, J. Knobe, A Talent for Bricolage. An Interview with Richard Rorty, wywiad Joshuy Knobe z Rortym ze stycznia 1995 roku, opublikowany w „The Dualist”, nr 2, 1995, s. 56-71 oraz w wersji elektronicznej dostępny: http://www.unc.edu/\%7Eknobe/rorty.html [15.03.2008] 
Należy się również kilka słów wyjaśnienia w kwestii trzech wydarzeń wspominanych przez autora Przygodności, ironii i solidarności w poniższym fragmencie. Chodzi tutaj o kongres Amerykańskiego Stowarzyszenia Filozoficznego w 1979 roku oraz dwa cykle wykładów: The Clark Lectures oraz The Massey Lectures. Rorty opowiada o roli, jaką odegrał pełniąc w 1979 roku funkcję prezesa zachodniego oddziału Amerykańskiego Stowarzyszenia Filozoficznego. Rok ten był niezwykle ważny dla amerykańskiej filozofii, gdyż dokonała się wówczas eskalacja konfliktu między filozofami analitycznymi a tzw. „pluralistami”. Rorty jako prezes musiał opowiedzieć się po którejś ze stron. Jeśli zaś chodzi o wspominane cykle wykładów, to filozof przyznaje, że miały one duży wpływ na napisane przez niego książki. The Clarks to wykłady organizowane przez Trinity College na Uniwersytecie w Cambridge, odbywające się z reguły co dwa tygodnie w Clark Café, we wtorki. Ich tematyka ściśle wiąże się z literaturą i sztuką ${ }^{8}$. Natomiast The Masseys są dorocznym wydarzeniem naukowo-kulturalnym, zapoczątkowanym w 1961 roku, upamiętniającym postać gubernatora Kanady, Vincenta Massey'a, a organizowane przez Uniwersytet w Toronto. Zapraszani goście specjalni, przedstawiciele kanadyjskiego lub zagranicznego świata naukowego, wygłaszają tygodniowe cykle wykładów na tematy polityczne, kulturalne lub filozoficzne. Najbardziej znane osobistości, wygłaszające wykłady w ramach The Masseys to: Martin Luther King Jr. (1967), Claude Lévi-Strauss (1977), Willy Brandt (1981), Carlos Fuentes (1984), Doris Lessing (1985), Noam Chomsky (1988) oraz Charles Taylor (1991) ${ }^{9}$. Sam fakt zaproszenia Rorty'ego do wygłoszenia wykładów w obu tych cyklach uznać należy za wielkie wyróżnienie.

Autor Filozofii a zwierciadła natury opowiada nam o swojej filozoficznej drodze, drogę tę Andrzej Szahaj nazywa drogą heretyka i wieszcza. Heretykiem jest on, ponieważ $\mathrm{z}$ jednej strony zrywa on $\mathrm{z}$ dominującym wówczas analitycznym nurtem filozofii amerykańskiej, z drugiej zaś - zrywa z filozofią poszukującą prawd i praw niezmiennych, pragnącą uchwycić naturę rzeczywistości. Odchodzi od przekonania, że filozofia jest jakąś szczególną dziedziną odkrywającą to, co zakryte, i deszyfrującą to, co zakodowane. Sam pisze w jednej ze swoich książek, że „nie podchodzi już do filozofii jako do określonej dyscypliny, fachu, pola profesjonalnych badań, ale traktuje ją jako głos w dyskusji”"10. Filozofia jest dla niego konwersacją, zderzeniem wielości dyskursów, „uwalnia ludzi od presji prawd przyznających sobie obiektywną,

\footnotetext{
Zob. więcej na oficjalnej stronie wykładów: http://www.trin.cam.ac.uk/index.php? pageid $=240$ [20.03.2008].

Zob. więcej na oficjalnej stronie wykładów: http://www.cbc.ca/ideas/massey.html [20.03.2008].

10 R. Rorty, Filozofia a zwierciadło natury, przeł. M. Szczubiałka, Warszawa 1994, s. 346.
} 
a często i absolutną ważność, które ograniczają ludzką wolność"11. Wskazuje, że należy porzucić wszelkie próby „ujęcia w jednej wizji wszystkich aspektów naszego życia, prób opisania ich za pomocą jednego języka"12. Stąd bierze się dystans Rorty'ego względem takich kategorii, jak prawda czy obiektywność, oraz przekonanie o niemożliwości stworzenia metafizyki. Jak sugeruje A. Szahaj, Rorty próbuje bronić nas przed przedstawicielami i bojownikami apodyktycznych prawd i ostatecznych rozwiązań, przed tyranią i kneblowaniem ust ${ }^{13}$, dlatego właśnie należy nazwać go również wieszczem. Rortiański filozof i intelektualista to zdystansowana względem swojej wizji świata i własnego systemu przekonan „liberalna ironistka”, świadoma przygodności swego otoczenia i życia, świadoma wielości języków, obrazów i wyjaśnień. Wszystko to czyni Rorty'ego filozofem niezwykle wyrazistym, którego poglądy niejednokrotnie budziły kontrowersje i spory, rodziły wszechstronne krytyki. Czytając poniższy fragment wywiadu z nim powinniśmy cały czas mieć to na uwadze.

1 A. Szahaj, Ironia i mitość. Neopragmatyzm Richarda Rorty'ego w kontekście sporu o postmodernizm, Wrocław 2002, s. 26.

12 R. Rorty, Przygodność, ironia i solidarność, przeł. W. J. Popowski, Warszawa 199, s. 15.

13 A. Szahaj, Prawda nienawiść, „Principia. Ekspres Filozoficzny”, nr 42, grudzień 2007, s. 58. 